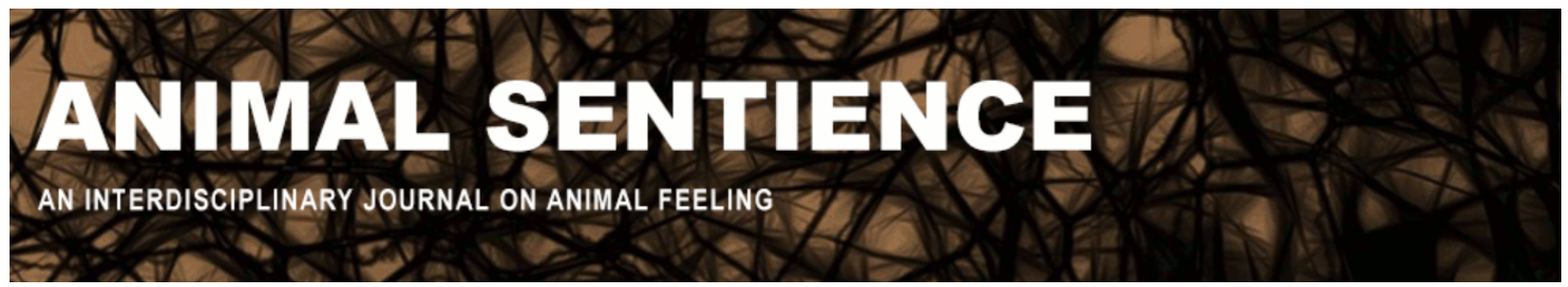

Cammaerts, Marie-Claire (2020) Invertebrates should be given ethical consideration. Animal Sentience 29(6)

DOI: 10.51291/2377-7478.1587

Date of submission: $2020-06-12$

Date of acceptance: 2020-06-15 (c) 


\title{
Invertebrates should be given ethical consideration
}

Commentary on Mikhalevich \& Powell on Invertebrate Minds

\author{
Marie-Claire Cammaerts \\ Biology of Organisms Department, University of Brussels, Belgium
}

\begin{abstract}
Invertebrates are far more numerous than vertebrates. Most of them are essential to the survival of humanity. Their physiology, behavior, know-how, and cognitive abilities are often as complex as those of vertebrates. Invertebrates should be considered and studied as are vertebrates, i.e., ethically, and cautiously.
\end{abstract}

Marie-Claire Cammaerts studies ant
behavior, cognition, and the
development of their abilities, such
as numerosity, and as biological
models for examining the effects of
products (e.g., drugs) used by
humans. Website

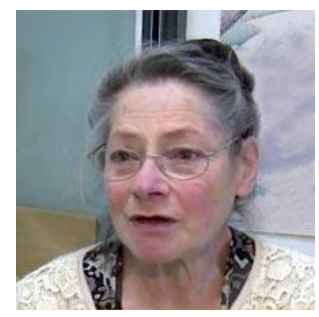

I develop three ideas that agree with the ethical concepts of Mikhalevich \& Powell (2020), could improve invertebrates' environmental conditions, and would allow efficient scientific research with them to continue.

1. Importance of invertebrates. Invertebrates are far more numerous than vertebrates. They often play very important roles in several ecosystems. Earthworms improve the quality of the soil. Many insects, hymenoptera among others, are excellent pollinators; we have fruits, seeds, and vegetables thanks to them. Most insects help recycle the organic compounds of litter. Flying insects are food for birds. Some invertebrates provide products used by humans, e.g., honey. Most of the earth's invertebrates are essential; they should be accorded more consideration and study (Lavelle, Aubert, Barot, Blouin, Bureau, Margerie, Mora \& Rossi, 2006; Cardoso, Erwin, Borges \& New, 2011). Aquatic invertebrates are also very important. In rivers, bloodworms (larvae of chironomids) increase the quality of the water. In the oceans, marine invertebrates are consumed by fishes. Humans depend on invertebrates for their survival.

2. Cognitive abilities of some invertebrates. Hundreds of examples could be given to show that invertebrates have cognitive abilities similar to those of vertebrates: e.g., migration, territorial marking, sexual behavior, brood caring, food collection and so on. Here, I will only discuss ants and present a few photos in Figure 1. These social insects navigate using learned cues, recruit nestmates, mark several parts of their living area differentially, take care of their brood, clean their nests, and build cemeteries (Passera \& Aron, 2005). They can recognize themselves in a mirror (like some vertebrates); when they hatch, they imprint on the appearance of their congeners (like vertebrates); they learn several behaviors in the presence of older kin (like vertebrates) (Cammaerts \& Cammaerts, 2015a,b). Ants have unexpected numerical abilities: they have an innate left-to-right number line, and acquire the concept of zero during their first year of life (Cammaerts \& Cammaerts, 2020a,b,c). Ants 
can add and subtract one element if they have previously seen the result of the operation (Cammaerts \& Cammaerts, 2020a). They can acquire single and multiple symbols including zero, and can use symbols for adding (Cammaerts \& Cammaerts, 2020f, unpublished data). Their responses are influenced by distance and size cues and are governed by Weber's law (as in vertebrates) (Cammaerts \& Cammaerts, 2020d,e). In the future, other invertebrates will undoubtedly prove to have at least some of these abilities. Ants are sentient because analgesics have an impact on their tactile perception (see section 3 below).
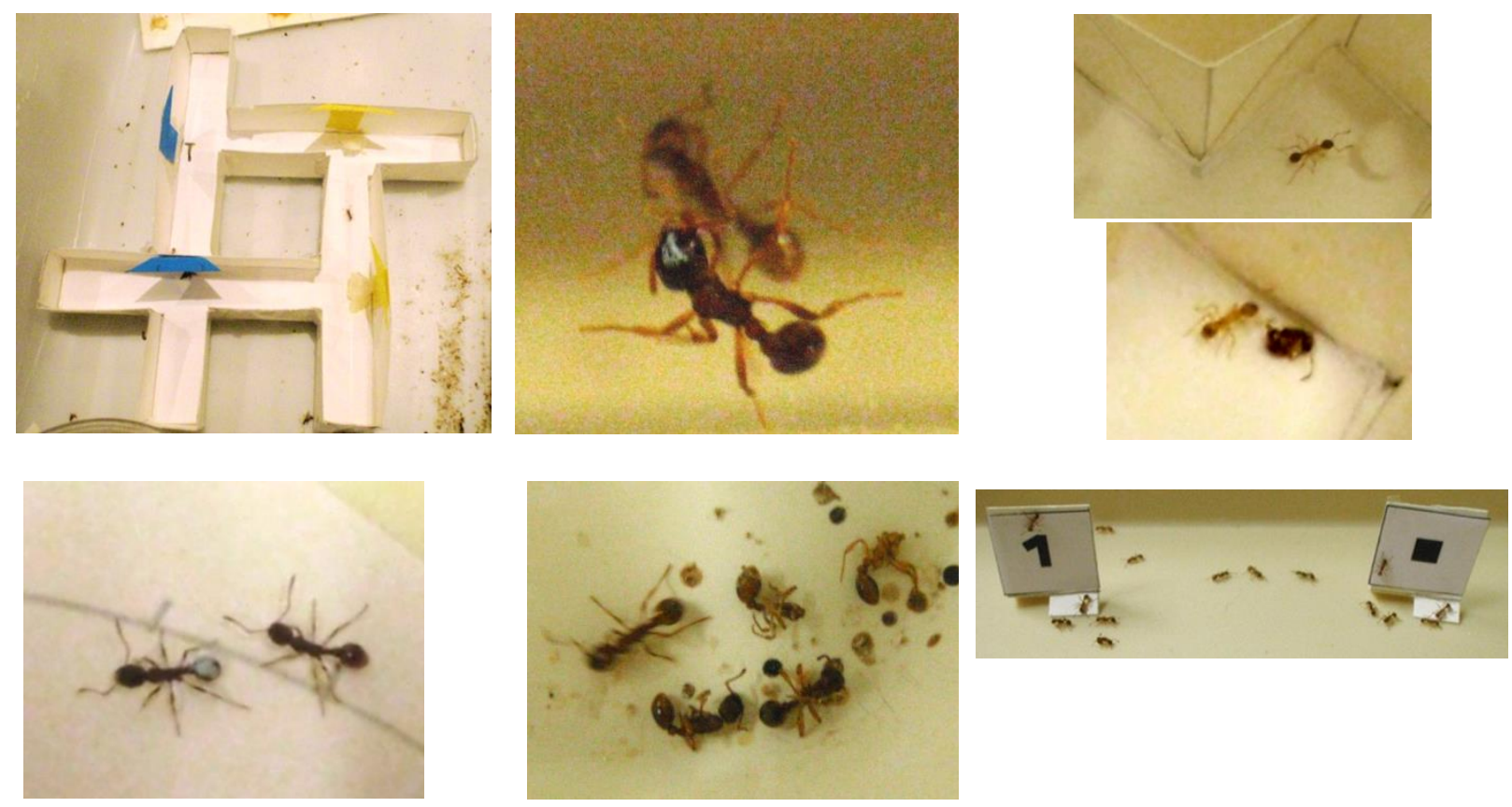

Figure 1

Upper left: ants navigating a maze after having learned visual cues.

Upper center: ant with a blue dot on its head, trying to clean it in front of a mirror.

Upper right: just hatched ants attracted by odor of nestmates (learned by habituation during the larval life) and by viewing a nestmate to whom it had imprinted upon hatching.

Lower left: ant learning to follow a trail by imitating an older nestmate (marked with a blue dot).

Lower center: ant cemetery.

Lower right: ants, after learning a symbol for 1 , respond equally to the symbol (on the left) and a square (on the right).

3. Invertebrates as biological models. Since most biological processes are similar for all animals, including humans (i.e., genetics, metabolism, nervous cell functioning), invertebrates and vertebrates can be used as models for studying biological questions (Kolb \& Whishaw, 2002; Wehner \& Gehring, 1999; Russell \& Burch, 2014). Invertebrates are used more and more because they have a short life cycle, a simple anatomy, and are small in size (Wolf \& Heberlein, 2003; Søvik \& Barron, 2013). Some species are commonly used as biological models, e.g., the flatworm Dendrocelium lacteum, the nematode worm Caenorhabdotes elegans, the mollusc Aplysia californica, the beetle Tribolim castaneum, the fruit fly Drosophila melanogaster, and the domestic bee Apis mellifera. Insects, especially social hymenoptera, are particularly widely used (Andre, Wirtz \& Das, 2008; Abramson, Wells \& Janko, 2007). Working on ants since 1969, I have examined on them, since 2014, the side effects of 36 products used by humans (antidepressants, analgesics - which affect ants' tactile perception - sweeteners, drugs, etc.) (Cammaerts, 2016, 2017, 2018, 2019). I have 
observed effects identical to those seen in humans, as well as undivulged effects, and could provide parametric information on these products such as how they decrease in efficiency after weaning, as well as the occurrence of some drug dependence. All these studies were done while maintaining the ants in the best possible environmental conditions (food, water, temperature, light, electromagnetic field, foraging area). This can - and should - be done whenever invertebrates are used as biological models, just as it is usually done in similar studies on vertebrates.

Conclusions. This commentary has provided scientific evidence on the topic treated by $M \& P$, using concrete examples, which are lacking in their target article. It largely confirms $M \& P^{\prime} S$ recommendation to consider invertebrates as sentient beings, as vertebrates are considered. I underscore the importance of invertebrates, their impact, and the part they play in the ecosystem; I accordingly advise protecting their environment. Using ants as a model, I demonstrate that even small invertebrates living in the ground have physiological, ethological and cognitive properties similar to those of vertebrates. I am in favor of using them as biological models for physiological and ethological studies, but doing so ethically. Our work on ants proves that this is perfectly realizable. Working and living in accordance with the recommendations of M\&P should still allow scientific progress and may even improve human life.

\section{References}

Abramson, C.I., Wells, H. \& Janko, B. (2007) A social insect model for the study of ethanol induced behavior: the honey bee. In Yoshida, R. (Ed.), Trends in alcohol abuse and alcoholism research. Nova Sciences Publishers, Inc., pp. 197-218.

Andre, R.G., Wirtz, R.A. \& Das, Y.T. (1989) Insect models for biomedical research. In A.D. Woodhead (Ed.), Nonmammalian animal models for biomedical research. Boca Raton, FL: CRC Press.

Cammaerts, M.-C. (2016) Ants as biological models for studying effects of substances used by humans. JSM Anatomy and Physiology 1: 1003.

Cammaerts, M.-C. (2017) Some findings on ants as models, which should be considered for caring of humans. MOJ Biology and Medicine 1 (5): 00027.

Cammaerts, M.-C. (2018) Ants as models for examining potential adverse effects of products used by humans. JSM Anatomy and Physiology 3 (1):1016.

Cammaerts, M.-C. (2019) Brief report of the effects of seven human drugs studied on ants as models. MOJ Biology and Medicine 4 (2): 42-47.

Cammaerts, M.-C. \& Cammaerts, R. (2015a) Are ants (Hymenoptera, Formicidae) capable of self recognition? Journal of Sciences 5 (7): 521-532.

Cammaerts, M.-C. \& Cammaerts, R. (2015b) Synopsis of the ants' acquisition of their cognitive abilities. Advanced Studies in Biology 7 (7): 349-350.

Cammaerts, M.-C. \& Cammaerts, R. (2020a) Ants' numerosity ability defined in nine studies. Journal of Biology and Life Sciences 11 (1): 121-142.

Cammaerts, M.-C. \& Cammaerts, R. (2020b) Young ants already possess a mental number line. International Journal of Biology 12 (2): 1-12.

Cammaerts, M.-C. \& Cammaerts, R. (2020c) Ants acquire the notion of zero through experiences. International Journal of Biology 12 (2): 13-25. 
Cammaerts, M.-C. \& Cammaerts, R. (2020d) Non-numerical distance and size effects in an ant. Journal of Biology and Life Sciences 11 (2): 13-35.

Cammaerts, M.-C. \& Cammaerts, R. (2020e) Weber's law applies to the ants' visual perception. Journal of Biology and Life Sciences 11 (2): 36-61.

Cammaerts, M.-C. \& Cammaerts, R. (2020f) Ants can associate a symbol with a number of elements through conditioning. International Journal of Biology 12 (3): 1-13.

Cardoso, P., Erwin, T.L., Borges, P.A.V. \& New, T.R. (2011) The seven impediments in invertebrate conservation and how to overcome them. Biological Conservation 144 (11): 2647-2655.

Kolb, B. \& Whishaw, I.Q. (2002) Neuroscience \& cognition: cerveau et comportement. Worth Publishers: New York, Basingstoke.

Lavelle, P., Decaens, T., Aubert, M., Barot, S., Blouin, M., Bureau, F., Margerie, P., Mora, P. \& Rossi, P. (2006) Soil invertebrates and ecosystem services. European Journal of Soil Biology 42 (1): S3-S15.

Mikhalevich, I. \& Powell, R. (2020) Minds without spines: Evolutionarily inclusive animal ethics. Animal Sentience 29(1).

Passera, L. \& Aron, S. (2005) Les fourmis: comportement, organisation sociale et évolution. Les Presses Scientifiques du CNRC: Ottawa, Canada.

Russell, W.M.S. \& Burch, R.L. (2014) The principles of humane experimental technique. Johns Hopkins University.

Søvik, E. \& Barron, A.B. (2013) Invertebrate models in addiction research. Brain Behavior and Evolution 82: 153-165.

Wehner, R. \& Gehring, W. (1999) Biologie et physiologie animales. De Boek Université, Thieme Verlag: Paris, Bruxelles.

Wolf, F.W. \& Heberlein, U. (2003) Invertebrate models of drug abuse. Journal of Neurobiology 54: 161-178. 


\section{$\$$ Summer School 2020 INNOVATIVE SCIENCE WITHOUT ANIMALS}

\section{June 22-26, 2020}

\section{Online Virtual Conference}

\section{Calling all students and early-career researchers!}

Join us for a FREE conference on innovative approaches in toxicology and biomedical sciences!

\section{This event features:}

- Lecture sessions about modern alternatives to the use of animals in toxicology and biomedical sciences

- Virtual laboratory tours

E-poster presentations

- Virtual engagement with speakers and attendees

Deadline to apply for the full program is June 10. Registration for individual lectures is available.

For more information visit InnovativeScience2020.org

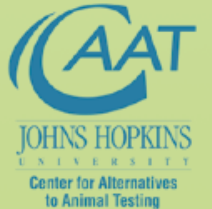

Physicians Center for Aitternalives

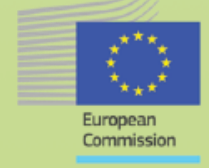

